\title{
Haemopoetic Stem Cell Transplantation in Autoimmune Diseases, with Special Reference to Rheumatoid Arthritis
}

\author{
John A Snowden BSc (Hons), MBChB, MD, MRCP (UK), MRCPath
}

Jpn. J. Clin. Immun., 23 (6) : 490 493, 2000.

Department of Haematology, Leicester Royal Infirmary, Leicester, UK

The idea of using haemopoietic stem cell transplantation (HSCT) as a treatment for severe autoimmune disease has been supported by over two decades of laboratory studies in which various forms of animal autoimmune diseases have been cured, reversed or prevented by allogeneic, syngeneic and autologous bone marrow transplantation. Evidence in humans has been provided by patients with autoimmune disease who have received HSCT for malignancy or aplastic anaemia. Such cases suggest allogeneic HSCT to be potentially curative of autoimmune disease. However, the substantial morbidity and mortality associated with allogeneic HSCT in its present form preclude its application to most patients with autoimmune disease. Although data from 'coincidental' cases suggested that autologous HSCT offers a lesser chance of cure, substantial remissions are possible and the treatment related risks are arguably acceptable for an experimental therapy for severe life threatening or chronically disabling autoimmune disease resistant to conventional therapies $(1,2)$.

The First International Meeting in Stem Cell Therapy in Autoimmune Disease was held in Basel, Switzerland in 1996. Subsequently consensus guidelines were published and the International Autoimmune Disease Stem Cell Project Database was established (3). To date over 300 cases of rheumatic, neurological and haematological autoimmune diseases have been registered, almost entirely of patients who have undergone autologous HSCT. The immediate objective of the database is to establish the best candidate diseases for this intensive approach, both in term of tolerability and efficacy. By 2001, the EBMT/EULAR Autoimmune Disease Working Party (Chair, Professor Alan Tyndall, Basel) aims to have in progress a number of controlled trials in various autoimmune diseases.

A significant number of clinical reports have now appeared in the literature in which a variety of HSCT regimens have been used to treat a diverse selection of severe autoimmune and inflammatory diseases including multiple sclerosis, systemic lupus erythematosus, scleroderma, relapsing polychondritis, and haematological diseases such as immune thrombocytopenia and Evans' syndrome. It is not possible to describe the outcome of each case in detail here and the reader is referred to the original articles and a recent review (4). This lecture will focus on rheumatoid arthritis.

\section{Rheumatoid arthritis}

Severe resistant rheumatoid arthritis (RA) may be 
John A Snowden - Haemopoetic Stem Cell Transplantation in Autoimmune Diseases, with Special Reference to Rheumatoid Arthritis

considered to be a good candidate disease for high dose therapy and autologous HSCT: there are many patients with resistant disease, efficacy is casily and non-invasively assessed and it is possible to select patients with good vital organ function who would be expected to tolerate high dose therapy well.

At St. Vincent's Hospital, Sydney the first phase of our strategy was to investigate the safety and efficacy of stem cell mobilisation in severe RA. In a double blind placebo controlled dose escalation study, flare occurred in $3 / 10$ patients treated with $G$ -CSF compared with $0 / 6$ receiving placebo. Adequate $\mathrm{CD} 34+$ cells were collected in all patients and achieved with a single apheresis in patients receiving G-CSF $10 \_\mathrm{g} / \mathrm{kg} /$ day (5). One other report has suggested that mobilisation flare might be prevented with pretreatment with steroids (6). The use of cyclophosphamide priming with G-CSF may be advantageous in such cases and may also add therapeutic benefit (7).

As the toxicity of high dose cyclophosphamide had never been formally established in RA, the next stage in our strategy was a phase I/ II dose escalation study of cyclophosphamide first at $100 \mathrm{mg} / \mathrm{kg}$ then $200 \mathrm{mg} / \mathrm{kg}$ followed by unmanipulated autologous PBSCT (8). The procedure was well tolerated in all patients with dose dependent toxicity. The clinical responses in the cohort receiving cyclophosphamide at $100 \mathrm{mg} / \mathrm{kg}(\mathrm{n}=4)$ lasted only $2-3$ months but the responses following cyclophosphamide at $200 \mathrm{mg} / \mathrm{kg} \quad(\mathrm{n}=4)$ were more impressive with significant clinical improvement sustained beyond 17-19 months in all patients. Increases in disease activity were observed but these responded well to the reintroduction of disease modifying agents. To address the role of $\mathrm{T}$-cell depletion, an Australian multicentre trial in which patients received cyclophosphamide $200 \mathrm{mg} / \mathrm{kg}$ and are then randomized to either unselected or selected grafts was set up. Recruitment has finished and results will be published shortly.
Other centres have published encouraging results in inflammatory arthritis using various protocols. In Perth, Australia, Joske and colleagues reported a 48 year old wheelchairbound man with severe refractory RA who had a profound response to cyclophosphamide $200 \mathrm{mg} / \mathrm{kg}$ followed by an unmanipulated autograft (9). In Belgium, Durez and colleagues reported a 22 year old patient with refractory systemic and erosive RA who was treated with busulphan $16 \mathrm{mg} / \mathrm{kg}$ and cyclophosphamide $120 \mathrm{mg} / \mathrm{kg}$ followed by rescue with a highly purified autograft. She remains free of joint symptoms at eleven months (10): Burt and colleagues in Chicago have reported four patients with $\mathrm{RA}$ treated with a CD $34+$ cell enriched autograft with sustained responses in two patients (11). In Omaha, a 25 year old female with a 7 year history of RA received cyclophosphamide $200 \mathrm{mg} / \mathrm{kg}$ and ATG 60' $\mathrm{mg}$ prior to and $60 \mathrm{mg}$ following infusion of unimanipulated autograft. At riday +100 there were-major reductitons in disease activity (12).

The Dulch collaborative group has treated 8 patients with active, progressively erosive RA who have failed at least 4 disease modifying antirheumatic drugs. Patients were treated with cyclophosphamide $200 \mathrm{mg} / \mathrm{kg}$ before haemopoietic rescue with $\mathrm{CD} 34$ +enriched harvests. Although no complete remissions were seen, significant improvements of disease activity were observed in all patients with 2-12 months follow up. Five patients are off antirheumatic drugs. One patient experienced a flare several weeks after transplantation, which responded to low dose prednisone and methotrexate (13). Also in the Netherlands, Wulffraat and colleagues have treated four patients with refractory juvenile chronic arthritis with cyclophosphamide $200 \mathrm{mg} / \mathrm{kg}$, ATG $20 \mathrm{mg} / \mathrm{kg}$ and $4 \mathrm{~Gy}$ total body irradiation (TBI) followed by rescue with bone marrow depleted of $T$ cells to a level of less than $10^{5} / \mathrm{kg}$. At twelve months, three are in remission and one has mild oligoarticular disease without systemic activity (14). 
In Leeds, six patients with RA resistant to 4 DMARDs have received treatment with cyclophosphamide $200 \mathrm{mg} / \mathrm{kg}$ and double selected autograft. No serious complications occurred either during autograft or up to 21 months of follow up. All six patients have responded $(2 \times A C R 20,3 \times A C R 50$ ald $1 \times A C R \quad 70$ ). One patient continues at ACR 50/20 at six months, but five patients relapsed at 1-9 months. However, these have made subsequent responses to cyclosporin $\mathrm{A}$ or cyclosporin $\mathrm{A}$ with methotrexate $(2 \times A C R \quad 50,1 \times$ complete remission, one no response, $1 \times$ insufficient follow up). This data supports use of early salvage or maintenance treatment following a 'debulking' of disease by the high dose treatment (15).

At the Royal Melbourne Hospital, a 38 year old man with severe resistant seronegative rheumatoid arthritis achieved remission for over 24 months after cyclophosphamide, ATG and a syngeneic PBSC transplant (16).

\section{Conclusion and future directions}

From the limited data available, high dose therapy and autologous HSCT seems to be producing promising results in RA and other autoimmune diseases, although like malignancy, there seems to be a heterogeneity of response. The mechanism of action is not clear, but may merely represent a combination of cytotoxic 'debulking' of the diseased tissue (e.g. rheumatoid synovium) and altered immune reconstitution following autologous HSCT. A higher grade 'hope', supported by some animal data and the observation of tolerance following allogeneic HSCT, is that of a tolerised immune system. Clearly, this approach is far more attractive if clinical improvement can be achieved without non-specific immune suppression and the potential for 'reeducation' of the immune system with autologous HSCT is currently being studied.

There are several avenues for clinical trials: 1 ) Further intensification of the cytotoxic regimen may result in greater 'debulking' of disease, although this must be balanced against safety. 2) Clinical trials of graft manipulation may answer the question of whether reinfusion of 'autoreactive' $T$ cells or other immune effectors are a source of treatment failure. 3) Post transplant maintenance or early salvage therapy should be studied. In addition, patient selection may be important. Analysis of greater numbers may identify subgroups of patients more responsive to therapy than others e.g. short duration of RA, presence of absence of rheumatoid factor, HLA-DRB 1 type. Eventually, the aim should be for randomised phase III trials against the best alternative treatment. As numbers of patients undergoing autologous HSCT will be limited, multicentre collaboration will be essential.

There have been recent advances in allogeneic HSCT in the form of low intensity or 'miniallografts' (17). If improved safety is confirmed, it may be acceptable to consider their use in some life-threatening autoimmune diseases, although this is likely to be restricted to the minority of patients with compatible siblings. As most severe autoimmune diseases cause severe compromise in function and quality of life but are not immediately life threatening, investigators should tread carefully and safety considerations should be paramount.

\section{REFERENCES}

1. Ikehara S. Intractable diseases and bone marrow transplantation. Pathology International $1994 ; 44: 817-26$

2. Snowden JA, Brooks PM, Biggs JC. Haemopoietic stem cell transplantation for autoimmune diseases. British Journal of Ilaematology $1997 ; 99: 9-22$

3. Tyndall A \& Gratwohl A. Blood and marrow stem cell transplants in autoimmune discase. A consensus report written on behalf of the European League against Rheumatism (EULAR) and the European Group for Blood and Marrow Transplantation (EBMT). Bone Marrow Trans- 
John A Snowden - Haemopoetic Stem Cell Transplantation in Autoimmune Diseases, with Special Reference to Rheumatoid Arthritis

plantation $1997 ; 19: 643-645$

4. Snowden JA \& Brooks PM. Hematopoietic stem cell transplantation in rheumatic diseases. Current Opinion in Rheumatology $1999 ; 11: 167-$ 172

5. Snowden JA, Biggs JC, Milliken ST, Fuller A, Staniforth D, Passuello F, Renwick J, Broòks PM. A randomised, blinded, placebo-controlled, dose escalation study of the tolerability and efficacy of filgrastim for haemopoietic stem cell mobilisation in patients with severe active rheumatoid arthritis. Bone Marrow Transplantation 1998;22: 1035-1041

6. McGonagle D, Rawstron A, Richards S, Isaacs J, Bird H, Jack A, Morgan G, Emery P. A phase I study to address the safety and efficacy of granulocyte colony stimulating factor for the mobilisation of hematopoietic progenitor cells in active rheumatoid arthritis. Arthritis \& Rheumatism 1997 ; 40 : 1838-1842

7. Breban M, Dougadous M, Picard F, Zompi S, Marolleau J-P, Bocaccio C, Heshmati F, Mczicre M, Dreyfus F, Bouscary D. High dose cyclophosphamide and granulocyte colony stimulating factor administration for hematopoietic stem cell mobilization in refractory rheumatoiid arthritis. Arthritis \& Rheumatism 1999 ; $42: 2275-2280$

8. Snowden JA, Biggs JC, Milliken S, Fuller A, Brooks PM. A phase I/II dose escalation study of intensified cyclophosphamide with autologous blood stem cell reseuc in severe active rheumatoid arthritis. Arthritis \& Rheumatism $1999 ; 42: 2286$ $-92$

9. Joske DJL, Ma DT, Langlands DR, Owen ET. Autologous bone marrow transplantation for rheumatoid arthritis. Lancet $1997 ; 350: 338$

10. Burt RK, Georganas C, Schroeder J, Traynor A, Stelka J, Sheucning F, Graziano F, Mineishi S, Brush M, Fishman M, Wells C, Rosen S, Pope R. Autologous hematopoietic stem cell transplantation in refractory rheumatoid arthritis. Sustained response in two of four paticnts. Arthritis \& Rheumatism $1999 ; 42: 2281-2285$

11. Durez P, Toungouz M, Schandene L, Lambermont, Goldman M. Remission and immune reconstitution after $\mathrm{T}$-cell-depleted stem-cell transplantation for rheumatoid arthritis. Lancet 1998 ; $352: 881$

12. Pavletic ZS, O’Dell JR, Bishop MR, Kessinger A, Reed EC, Ursick MM, Maher K, Haire CE, Armitage JO, Klassen LW. Treatment of refractory rheumatoid arthritis utilizing an outpatient autologous blood stem cell transplantation protocol (abstract). Blood 1998;92 suppl 1:370 b

13. van Laar JM, Verburg RJ, van den Hoogen FHJ, Fibbe WE, Preijcrs F, Schattenberg AVMB, van der Putte LBA, Breedveld FC. Autologous stem cell transplantation for refractory rheumatoid arthritis. Bone Marrow Transplantation $2000 ; 25$ suppl $1: \mathrm{S} 114$

14. Wulffraat NM, van Royen A, Bierings M, Vossen JM, Kuis W. Autologous hemopoietic stem cell transplantation in four cases with refractory juvenile chronic arthritis. Lancet $1999 ; 353: 550-553$

15. Bingham SJ, Snowden J, McGonagle D, Richards S, Isaacs J, Morgan G, Emery P. Autologous stem cell transplantation for rheumatoid arthritis -report of six patients. $J$ Rheumatol 2000; in press

16. McColl G, Kohsaka H, Szer J, Wicks I. Highdose chemotherapy and syngeneic hemopoietic stem-cell transplantation for severe, seronegative rheumatoid arthritis. Annals of Internal Medicine $1999 ; 131: 507-9$

17. Slavin S, Nagler A, Naparstek E, Kapelushnik Y, Aker M, Cividalli G, et al. Non-myeloablative stem cell transplantation and cell therapy as an alternative to conventional bone marrow transplantation with lethal cytoreduction for the treatment of malignant and non-malignant hematologic diseases. Blood $1998 ; 91: 756-763$ 